\title{
Formation and transport of photooxidants over Europe during the July 2006 heat wave - observations and GEM-AQ model simulations
}

\author{
J. Struzewska ${ }^{1}$ and J. W. Kaminski ${ }^{2}$ \\ ${ }^{1}$ Faculty of Environmental Engineering, Warsaw University of Technology, Warsaw, Poland \\ ${ }^{2}$ Atmospheric Modelling and Data Assimilation Laboratory, Centre for Research in Earth and Space Science, York \\ University, Toronto, Canada
}

Received: 30 May 2007 - Published in Atmos. Chem. Phys. Discuss.: 19 July 2007

Revised: 30 October 2007 - Accepted: 12 January 2008 - Published: 13 February 2008

\begin{abstract}
The European heat wave of July 2006 was caused by advection of very hot and dry air from North Africa. Air masses were transported on the western edge of the high pressure system, centred over Eastern Europe, resulting in exceptionally high air temperatures over large areas of the continent. In the first two weeks of July 2006 a severe heat wave affected Central and North-Eastern Europe. We present a synoptic analysis of the July 2006 European heat wave, resulting formation and transport of photooxidants over Europe as simulated by the on-line tropospheric chemistry model GEM-AQ. The model was executed on a global variable grid with $\sim 15 \mathrm{~km}$ resolution over the entire European continent. Modelling results have been compared with surface observations and vertical soundings of meteorological and air quality parameters. We find that the calculated error measures, as well as analysis of time series and trends for selected quantities, indicate good model performance over the simulation period. The spatial pattern of two exposure indicators - SOMO35 and AOT40 - showed similarities with the high temperatures distribution. The zone of highest exposure was located over Central Europe along the advection path of the hot African air mass. The exposure to high ozone concentrations in higher latitudes was reduced by the dilution and aging of polluted air masses advected from over Central Europe.
\end{abstract}

\section{Introduction}

During the last 60 years, several exceptionally hot summer periods have been observed. For example, the averaged maximum temperature in 1947 was $\sim 5^{\circ} \mathrm{C}$ above the long term

Correspondence to: J. Struzewska

(joanna.struzewska@is.pw.edu.pl) average value. Positive temperature anomalies of over $2^{\circ} \mathrm{C}$ have been recorded during the summer months of 1976, 1983 and 1994 (Beniston and Diaz, 2004). In 2003 the mean JuneJuly-August temperature exceeded the 1961-1990 mean by $3^{\circ} \mathrm{C}$ over a large area (Schär et al., 2004; DWD, 2003). For Central Europe, the frequency of heat wave occurrence has been investigated using temperature records for the period 1982-2000. Seventeen consecutive periods of at least 3 days, during which the daily maximum temperature was higher than $30^{\circ} \mathrm{C}$, were detected between the beginning of June and the end of August (Kysely, 2004). According to the analysis undertaken in the frame of IPCC, in Central Europe eight of the ten warmest years in the 1851-2004 period have been observed from 1989 to 2003 (IPCC, 2001; Jones and Moberg, 2003). Analysis by Scherrer et al. (2005) confirmed the increasing variability of the temperature, found in particular for the June-July-August season in 1975-2004. A recent climate modelling study showed that European summer surface temperature variability might further increase within the current century (Schär et al., 2004).

Prolonged periods characterised by exceptionally high air temperature have several adverse environmental impacts which can affect human health. Analyses in European cities show that total mortality rises with the temperature increase in the summer, especially during heat wave episodes (McMichael and Kovats, 1998; Rooney et al., 1998; Katsouyanni et al., 1988, 1993; Kunst et al., 1993; Jendritzky et al., 1997). Such periods, often associated with strong, blocking high pressure systems, are also favourable for generation of photochemical episodes. Higher temperatures and irradiance result in enhanced biogenic VOC emission and more intensive photochemical processes which increase ozone formation. Ozone is considered to be one of the most important environmental health problems in Europe. High

Published by Copernicus Publications on behalf of the European Geosciences Union. 
photochemical pollutants concentration, interacting with extreme air temperature, may have harmful health effects and damage crops, and forests (Filleul et al., 2006; Katsouyanni et al., 1993). The increasing frequency and intensity of heat waves over Europe is believed to present evidence of climate change and global warming. Comparatively small shifts in the seasonal mean temperature may imply pronounced changes at the tails of the statistical distribution which represents extreme events (Schär et al., 2004).

Two recent heat wave periods are extensively documented in the literature, with respect to the impact on photochemical pollution: July-August 1994 and August 2003. A synthesis of these two events in the synoptic context are provided in the following subsections.

\subsection{Heat wave July-August 1994}

The heat wave period in July-August 1994 lasted 17 days. The meteorological situation was governed by the high pressure system, initially centred over the Baltic Sea. In the next few days the high pressure ridge extended towards the North Sea and the British Isles. Based on synoptic maps, very high temperatures were recorded over Southern Europe. In Western Europe the advection of the hot air masses formed over Sahara caused a significant temperature increase in many locations. After 23 July the heat wave also affected Central Europe.

During this period a prolonged summer smog episode occurred over Central and Western Europe. The hourly ozone concentrations exceeded $100 \mathrm{ppbv}$ over large areas. At the beginning of the episode (21 July-23 July), an ozone-rich air mass was transported with the prevailing easterly wind from the main emission regions of ozone precursors along the western and northern coasts of France and Spain, towards the North Atlantic. In the next few days, the ozone concentration increased further, and the polluted air mass was transported towards the North Sea (24-26 July) and to Scandinavia (27 July-30 July) (Memmesheimer et al., 1999; Langmann, 2000). The analysis of increased mortality during the period from 27 June to 7 August 1994 in Belgium confirmed that the number of premature deaths was associated with unusually high outdoor temperatures and elevated ozone levels (Sartor et al., 1995).

\subsection{Heat wave August 2003}

In the summer of 2003, the highest temperatures were recorded in Western Europe during the first half of August (WHO, 2004). This event was associated with a very robust and persistent high pressure system over Europe that blocked the flow of a rain-bearing low-pressure system at $700 \mathrm{mb}$ and $500 \mathrm{mb}$ (Lyamani et al., 2006). Some weather services suggested that this phenomenon might be a manifestation of an exceptional northward extension of the Hadley cell (Beniston and Diaz, 2004). Such synoptic conditions remained almost unchanged for the whole first half of August. Exceptionally high temperatures (often near $40^{\circ} \mathrm{C}$ ) and the stagnation of air masses over areas of high emissions caused a long-lasting, severe photochemical episode (Vautard et al., 2005). Very high ozone concentrations occurred mainly in the first half of August. The spatial distribution of exceedances of the information threshold (180 $\mathrm{g} \mathrm{m} \mathrm{m}^{-3}$ ) (Directive 2002/3/EC, 2002) observed in summer 2003 was much more extensive than in previous periods. The averaged daily 8 -h ozone concentration for the period June-August 2003 was $87 \mu \mathrm{g} \mathrm{m}^{-3}$, as compared to $71 \mu \mathrm{g} \mathrm{m}^{-3}$ in 2002 and $61 \mu \mathrm{g} \mathrm{m}^{-3}$ in 2000 (Fiala et al., 2003). In addition to enhanced photochemical pollution, Southern Europe also suffered from high concentrations of carbon monoxide and biomass burning particle aerosols emitted from wild fires in the Iberian Peninsula and mineral dust transported from the Sahara (Tressol et al., 2006; Lyamani et al., 2006).

High temperatures and poor air quality resulted in increased mortality in many European countries. 400-500 of the estimated 1000-1400 premature deaths in the summer period in the Netherlands occurred during the 31 July-13 August heat wave (Fisher et al., 2004). In the United Kingdom, an increase of about 2000 deaths during the same period was reported (Stedman, 2004). Mortality of an additional 28000 people was estimated for the southern part of Europe (Portugal, Balkans, Italy). In France about 15000 excess deaths were recorded, especially at the end of the episode (Hémon and Jougla, 2003).

\section{European heat wave of July 2006}

In the summer of 2006 an exceptionally hot weather period began in mid June. Western European countries experienced two heat waves, one from the end of June to the beginning of July, followed by a longer and more severe one from midJuly to the beginning of August. The highest temperatures during the period were recorded on 19 July in many locations. It has been confirmed by the weather services that in most European countries, July 2006 was the warmest month since official measurement started. During this period, heat related deaths were reported in France, Italy, Spain, Germany, the Netherlands and the United Kingdom. In addition to the impact on human health, abnormally high temperatures and very low rainfall destroyed many crops and caused droughts in most of Europe. Cuts in power supply occurred due to increased electricity usage by air conditioners and problems with power plants' cooling systems caused by rising river temperatures. In addition, ozone pollution was also very high, especially during days with extremely high air temperature and low wind speed.

South-Western Europe quite frequently experiences the inflow of sub-tropical air masses which can be advected towards Western Europe. The air temperature increase is enhanced if such situations are accompanied by a high pressure 
ridge or high pressure belt extending over Europe (as occurred during 1994 and 2003 heat waves). Further advection of hot air masses towards Central Europe can be blocked by a stable high pressure system and limited to situations in which the evolution of a pressure field allows for westerly or southwesterly circulation.

During the 1994 heat wave, the hottest period over Central Europe was associated with the advection of hot air masses from over south-western Europe. In summer 2003, high pressure over Central Europe as well as south-eastern anticyclonic circulation resulted in relatively weak advection, and high temperature affected mainly Western Europe.

The origin of the heat wave that influenced Central and North-Eastern Europe in July 2006 was different from cases described in previous sections. The specific location of pressure patterns allowed for an enhanced meridional circulation, resulting in high temperatures over this region. The synoptic situation is presented in Sect. 2.1.

At the beginning of July, Western Europe was influenced by the cold front with extreme events that ended the first heat wave period over this area. At the same time, Central Europe experienced very high temperatures, accompanied by high ozone concentrations. The location of pressure systems over the continent and the circulation patterns forced the transport of hot and dry air mass from over Algeria towards Central and North-Eastern Europe (Poland, Lithuania, Sweden). Prolonged hot weather may have particularly adverse impacts in this region because temperatures exceeding $30^{\circ} \mathrm{C}$ have been a rare phenomenon. In contrast to Southern European countries, there are no air conditioning systems in many offices, public transportation, private houses and cars. Working hours are also not adjusted to limit activity, and hence reduce exposure during noon hours. In this paper we will investigate the origin of the Central-Eastern European heat wave during the first two weeks of July and the impact of the exceptionally high temperature on the photochemical pollution over this area. The analysis will focus on the period from 3 July to 14 July.

\subsection{Synoptic situation - 3-14 July 2006}

Analysis of the synoptic situation is based on the surface weather maps and daily weather reports. In the beginning of the analysed period, the heat wave affected mainly Western Europe. Cyclonic circulation over this region forced the transport of air masses from over North Africa. On 3 July the highest temperatures were recorded in France, but hot air was also advected towards the British Isles; the temperature in London exceeded $32^{\circ} \mathrm{C}$. Over Central and Eastern Europe the circulation was governed by a robust and extended high pressure system centred over Ukraine. Warm air flowing on the western edge of the high pressure cell turned to the south over Scandinavia, towards the Baltic Sea and Central European countries. On 4 July these air masses reached Central Europe, causing the significant temperature increases that were observed in most measurement sites in Poland. Large scale subsidence resulted in decreased relative humidity and limited cloud formation. The clear sky conditions strengthened the heat wave effect. On 5 July, due to the slow eastward movement of a high pressure system, the winds over Central Europe changed direction from north-easterly to southerly. Very high temperatures, exceeding $30^{\circ} \mathrm{C}$, were recorded over Poland during the day, and temperatures remained relatively high overnight.

Starting on 6 July a high pressure ridge was established over Eastern Europe, and together with the low pressure system over North Africa allowed for the transport of subtropical, continental air masses towards Central and NorthEastern Europe. The advection of hot air from over Algeria sustained the high temperatures over Poland, Lithuania, Latvia and Sweden. Due to almost clear sky conditions, heat radiating from the land surface enhanced the temperature increase. Meanwhile, over Western Europe, a cold front associated with a low pressure trough started to influence the weather conditions. The inflow of humid and relatively cool Atlantic air masses over the hot land surface generated atmospheric instability. The thermal contrast between western and Central-Eastern Europe resulted in several extreme events. Severe gales and thunderstorms affected France, Switzerland and Germany. However, in Central Europe, due to very slow movement of the trough, blocked by the high pressure ridge as well as low specific humidity, the passage of the front did not result in a decrease in temperature. Cooler air flowing from the north was heated due to adiabatic descent and the sensible heat transfer near the hot surface. This situation remained almost unchanged during the following days.

After 12 July the cold front dissipated and hot African air again started to influence Western Europe. Very high temperatures were recorded in France, Spain, Portugal and Northern Italy. Eastern and South-Eastern Europe were under the influence of hot continental air from over Western Asia.

\subsection{Ozone pollution - 3-14 July 2006}

The description of the pollution episode is based on the available observations and EAA (European Environmental Agency) reports (http://www.eea.europa.eu/maps/ozone/ map). On 3 July and 4 high ozone concentrations occurred mainly in urban and suburban areas in Western Europe. During the next few days the passage of the cold front and the inflow of clean Atlantic air mass resulted in the decrease of ozone concentration over France (after 5 July) and over the UK (after 6 July). The near-surface eastward advection of the ozone-rich air, combined with the local production, resulted in the extended episode over Belgium, the Netherlands and Germany. High ozone concentrations transported northward over the North Sea and the Baltic Sea caused the elevated ozone concentration levels in Denmark, and the coastal sites in Sweden and Baltic countries. The low pressure trough pushed polluted air masses toward Central Europe. At the 


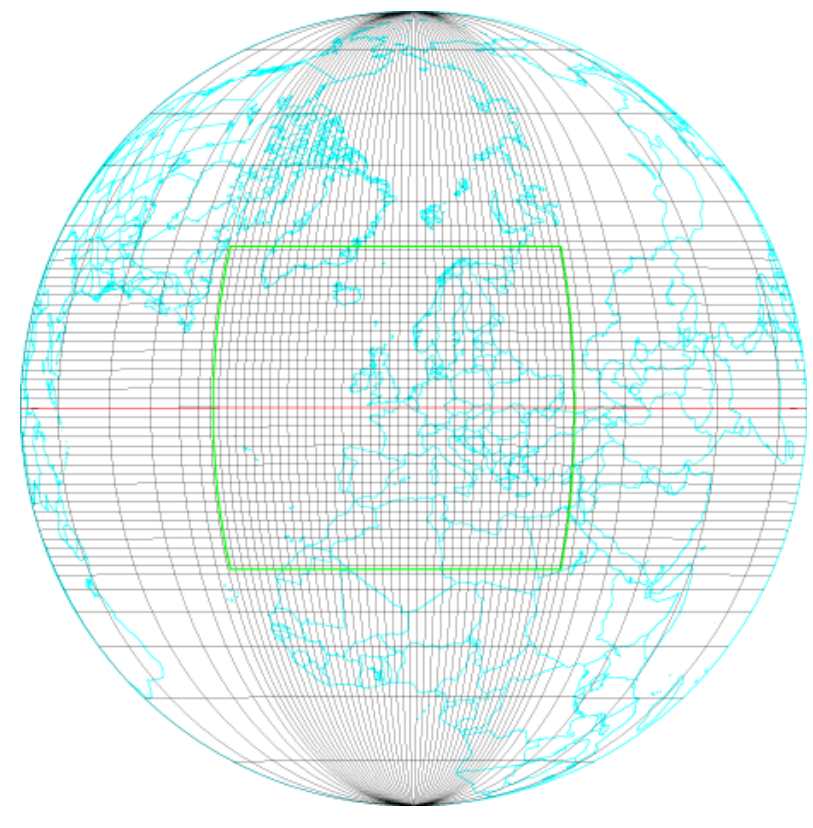

Fig. 1. Global variable resolution model domain (every 10th grid line is plotted).

same time, the flow of hot African air across Europe, and clear sky conditions associated with the high pressure ridge enhanced the local ozone production. The combination of these processes led to the occurrence of the elevated ozone concentration over large areas - extending from Southern to North-Eastern Europe during the following days. After 12 July high ozone concentrations were observed again in western and south-western parts of Europe.

The daily maximum 8 -h average ozone concentrations exceeded the threshold value over most of Europe. The area exposed to the 8-h ozone running average higher than $120 \mathrm{\mu g} \mathrm{m}^{-3}$, covering initially Western Europe (France and Germany) extended eastward and northward (towards Baltic countries, southern Finland and Russia). The highest exposures occurred over Central Europe.

\section{Modelling approach}

An on-line tropospheric chemistry model, GEM-AQ (Kaminski et al., 2007), was used to simulate the meteorological conditions and photochemical processes. The integrated model provides a consistent framework between the meteorological and air quality aspects of the atmospheric system, thus simplifying the use of the model as well as improving the accuracy of the predictions. The host meteorological model used in this study is the Global Environmental Multiscale (GEM) model developed by the Meteorological Service of Canada for operational weather prediction (Côté et al., 1998). GEM can be configured to simulate atmospheric pro- cesses over a broad range of scales, from the global scale down to the meso-gamma scale.

Air quality modules are implemented on-line in the host meteorological model. In this version of GEM-AQ, there are 36 advected and 14 non-advected gas phase species in the model. Transport of the chemically active tracers by the resolved circulation is calculated using the semi-Lagrangian advection scheme native to GEM. The vertical transfer of trace species due to subgrid-scale turbulence is parameterized using eddy diffusion calculated by GEM. The gas-phase chemistry mechanism used in this version of GEM-AQ comprises 50 species, 120 chemical reactions and 16 photolysis reactions representing air quality and free tropospheric chemistry. Time evolution of all specie is solved using a mass-conserving implicit time stepping discretization, with the solution obtained using Newton's method.

For the simulations carried out in the current study the model was configured with 28 hybrid vertical levels with model top at $10 \mathrm{hPa}$. Physical parameterizations employed in the model follow those presented by Mailhot et al. (2006).

The horizontal model grid was configured as a global variable resolution with a total of 565 by 480 grid points. The model grid, position of the computational equator, and the core section of the grid is shown in Fig. 1. The core section of the grid has 400 by 350 grid points and a uniform resolution of 0.1375 degrees $(\sim 15 \mathrm{~km})$. The model time step was set to $450 \mathrm{~s}$ for dynamics, physics and air quality processes. Meteorological initial conditions were taken form the Canadian Meteorological Centre global assimilation system (Gauthier et al., 2007; Laroche et al., 2007). The GEM-AQ model was run in $24 \mathrm{~h}$ forecast segments starting from 6-h trial fields generated in a separate GEM execution. This setup resulted in meteorological fields being forced to observations once a day. Chemical initial conditions were generated by GEM-AQ run in a global uniform configuration $\left(1.5^{\circ} \times 1.5^{\circ}\right)($ Kaminski et al., 2007).

The standard emission dataset used for global simulations was compiled using EDGAR2.0 (Olivier et al., 1996). For the current case study the EMEP emission data over Europe valid for the year 2003 have been used. The NMVOC flux was disaggregated to create the information on hydrocarbon groups specific for the GEM-AQ chemical mechanism. Emission fields were regridded from polar stereographic EMEP grid to uniform resolution of the core part of the model grid. The mass flux conservation was ensured after regridding. Although this method conserves the total flux, it leads to a reduced amplitude and horizontal spread of the emissions field that could result in changes of ozone production (Liu et al., 1987). In addition, emissions were distributed within the four lowest model layers, according to vertical profiles used in CityDelta Project (http://aqm.jrc.it/citydelta). EMEP emissions were merged with industrial EDGAR2.0 emissions, and the EMEP temporal variability profile was applied based on the local time in each grid cell. Biogenic climatological emissions for July were derived from the GEIA 


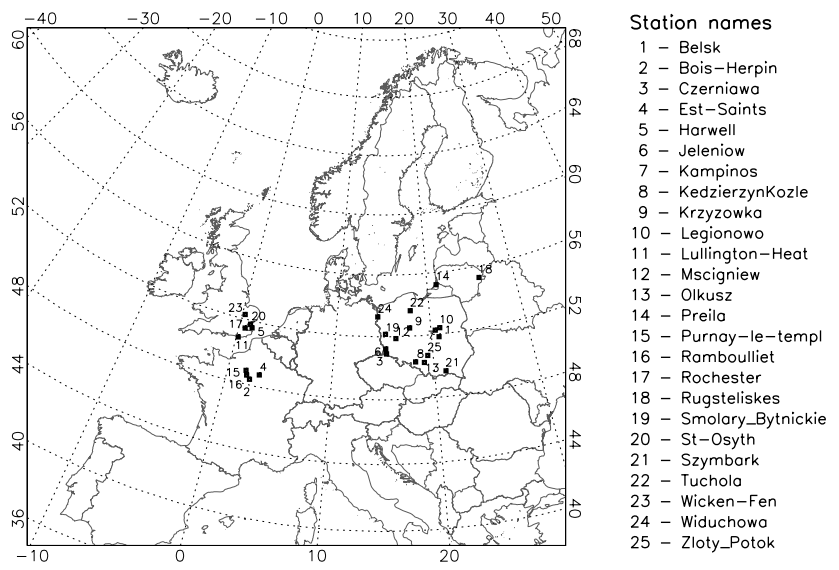

Fig. 2. Monitoring stations used for analysis.

inventory (monthly means). To obtain more realistic biogenic fluxes the diurnal variation profile was applied with the temperature-based empirical adjustment. We note that there are large uncertainties associated with biogenic emission rates (Simpson et al., 1995, 1999). Also, observations made by Lee et al. (2006), in the UK, suggest that during the 2003 heat wave biogenic isoprene emissions were increased significantly as compared to non-heat wave periods and the total VOC reactivity was doubled, resulting in higher ozone production. In our case such an evaluation of biogenic VOC emission fluxes was not possible due to the unavailability of hydrocarbon measurements in Central Europe.

\section{Model results and analysis}

GEM-AQ model results were compared with measurements of meteorological and air quality parameters. The spatial distribution of measurement sites is shown in Fig. 2. Considering the model resolution $(\sim 15 \mathrm{~km})$, only rural-background stations have been selected for the comparisons. Four stations from the AirParif network (France) and five stations located in England represent the variability of atmospheric pollution in Western Europe, where the passage of the cold front ended the heat wave and the ozone episode. Measurements from 14 monitoring stations in Poland and 2 stations in Lithuania allow for comprehensive analysis of air quality over Central Europe, where high ozone concentration persisted during the whole simulation period.

Statistical analysis of the model performance has been undertaken for ozone, $\mathrm{NO}_{2}$ and temperature. The correlation coefficient and three types of accuracy measures - MBE (mean bias error), MAGE (mean absolute gross error) and RMSE (root mean square error) were calculated for each station.
Table 1. Error statistics for surface ozone.

\begin{tabular}{lrrrr}
\hline Station & $\begin{array}{r}\text { Correlation } \\
\text { Name }\end{array}$ & MBE & MAGE & RMSE \\
\hline Bois Herpin & 0.73 & 4.26 & 24.35 & 29.22 \\
Est Saints & 0.69 & 9.01 & 26.17 & 31.41 \\
Purnay le templ & 0.75 & 16.47 & 24.23 & 28.74 \\
Ramboulliet & 0.73 & -2.08 & 20.87 & 28.56 \\
Harwell & 0.63 & -0.73 & 23.48 & 31.70 \\
Lullington Heat & 0.50 & -10.79 & 25.88 & 37.01 \\
Rochester & 0.70 & 0.62 & 19.79 & 27.42 \\
St Osyth & 0.70 & -4.59 & 20.31 & 27.83 \\
Wicken Fen & 0.61 & -4.45 & 23.07 & 31.75 \\
Preila & 0.59 & -1.14 & 18.93 & 26.68 \\
Rugsteliskes & 0.68 & 7.42 & 19.11 & 26.05 \\
Belsk & 0.71 & -4.75 & 18.64 & 24.41 \\
Jeleniow & 0.76 & -4.56 & 19.46 & 24.24 \\
Kampinos & 0.73 & 9.32 & 22.34 & 28.45 \\
Kedzierzyn Kozle & 0.75 & 27.73 & 32.02 & 42.58 \\
Krzyzowka & 0.77 & 2.39 & 18.28 & 25.58 \\
Legionowo & 0.77 & 4.33 & 22.84 & 28.52 \\
Mscigniew & 0.80 & -3.33 & 14.85 & 19.77 \\
Smolary Bytnickie & 0.71 & -1.95 & 18.40 & 24.15 \\
Szymbark & 0.78 & 14.21 & 18.54 & 24.02 \\
Tuchola & 0.80 & -8.28 & 21.57 & 27.51 \\
Widuchowa & 0.71 & -13.07 & 21.63 & 27.28 \\
Zloty Potok & 0.78 & -1.71 & 17.37 & 23.32 \\
\hline
\end{tabular}

\subsection{Surface ozone}

The error values and the correlation coefficient between modelled and measured ozone concentrations are given in Table 1 .

For most of the stations, the correlation coefficient is in a range $0.7-0.8$, which indicates good agreement of measured and modelled values with respect to diurnal ozone variation and changes in the trend. Less satisfactory correlation for sites in England is a consequence of the lack of spin up period. The simulation started on 3 July, and the model was not able to reproduce the episode in Western Europe for that day. MBE values showed that the model did not have a systematic bias. For most of the stations the error values are below $\pm 5 \mu \mathrm{g} \mathrm{m}^{-3}$. The very high MBE value for Kedzierzyn-Kozle station $\left(27.73 \mu \mathrm{g} \mathrm{m}^{-3}\right)$ is a result of insufficient emission inventory resolution; the impact of the emission from a nearby power plant was not captured by the model.

MAGE for all stations is about $21 \pm 4 \mu \mathrm{g} \mathrm{m}^{-3}$. The analysis of time series revealed that the largest discrepancies between modelled and measure values occurred during the night. The night time ozone overestimation is a well known problem in air quality modelling. The thickness of the bottom GEM-AQ model layer is $\sim 35 \mathrm{~m}$. During the daytime, due to developed mixing processes, the concentrations calculated for this layer are representative of the air quality measurements taken near the surface. However, during the night, due to the complex 


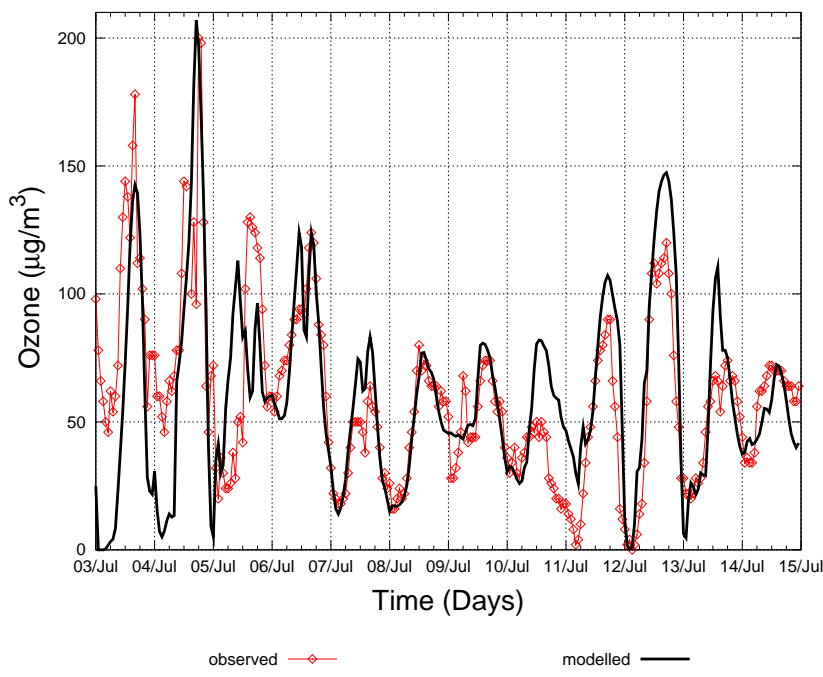

Fig. 3. Observed and modelled ozone time series at Rochester; 3-14 July, hourly values.

structure of the non-stationary stable surface layer, the modelled concentrations might be overestimated. The most probable reasons are: too intensive vertical mixing resulting in the mass exchange with the layer above, underestimated deposition flux and/or overestimated temperature.

The time series of the ozone concentrations have been analysed for all monitoring sites and compared with the model results. No constant pattern of bias has emerged. The observed temporal variability of ozone concentrations in the UK, France and Central Europe differs mainly due to different dynamical forcings described in Sect. 2.1. The four stations with representative observed variability patterns and low MBE were selected to illustrate these differences. In the UK, high ozone concentrations were measured on 3 and 4 July and decreased significantly due to the inflow of clean Atlantic air masses over the following days. Low ozone concentrations were recorded till the end of the analysed period (Fig. 3).

At the AirParif stations very high ozone values persisted till 4 July. After 5 July, due to frontal activity, a decrease in ozone concentrations was noted. However, after 12 July the ozone concentrations again reached high levels (Fig. 4).

The pattern observed in Central European stations is not as consistent as described for Western Europe. Due to the very slow movement of the frontal zone, the western part of Poland was influence by the trough, while the north-eastern part was influenced by the high ridge. In most stations in Poland, a rapid increase in ozone concentrations was noted till 8 July. During the following days, on some stations the ozone levels did not change until 12 July and decreased slightly at the end of the analysed period (Fig. 5). Other stations showed a slight decrease around the 9 and 10 of July and then further increased (Fig. 6). On 14 July ozone values decreased at all stations.

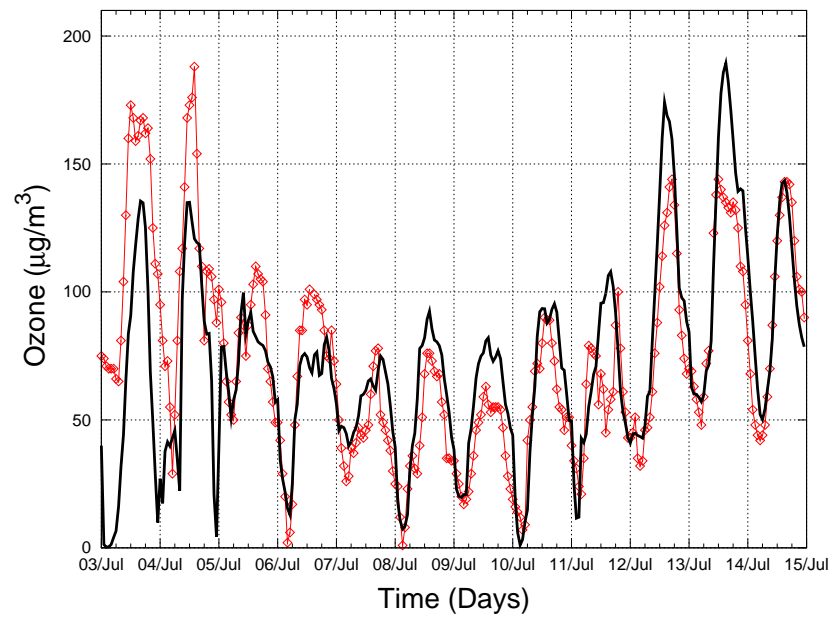

observed $\longrightarrow$

modelled -

Fig. 4. Observed and modelled ozone time series at Ramboulliet; 3-14 July, hourly values.

The comparison presented above confirms good agreement of modelled ozone concentrations with observations. Due to the lack of spin up period, there are differences in ozone concentrations at the model start time. In Western Europe initial conditions that were too low resulted in the underestimation of modelled ozone concentrations during the first two days, as confirmed by the levels observed in France and England. However, the decrease connected with the frontal passage and further increase in France associated with the second heat wave were reproduced correctly. In Central Europe, for most stations the model reproduced correctly the variation of ozone concentrations. However, for some stations the model underestimated daylight ozone concentrations on 12 and 13 July. The plausible reason for these discrepancies is probably connected with over-predicted modelled cloudiness, which will be discussed in Sect. 4.2.

The ability of the model to reproduce maximum ozone concentration was also investigated. Figure 7 shows the scatter plot of the observed and modelled daily maximum values for each day and each station. In general the model reproduced daily maximum with good accuracy, especially in the range of $100-150 \mu \mathrm{g} \mathrm{m}^{-3}$ for Central European stations. A small tendency to underestimate higher values at some stations has already been mentioned. Stations in Western Europe show larger variance, because in this area ozone concentrations are strongly influenced by dynamical factors. Larger discrepancies might also be explained by inadequate initial conditions for Western Europe. However, in most cases the relative difference between modelled and measured maximum concentrations does not exceed $20 \%$. 


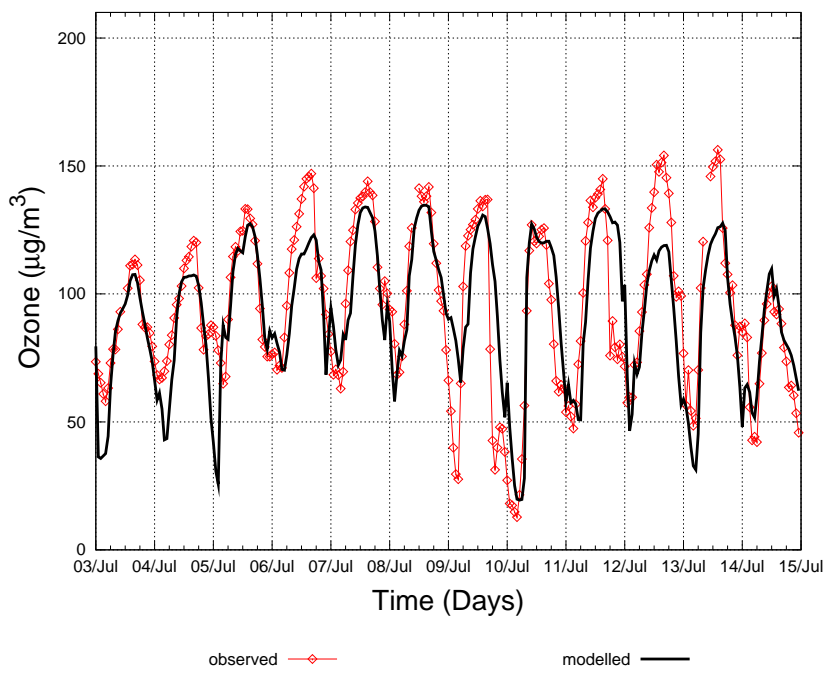

Fig. 5. Observed and modelled ozone time series at Mscigniew; 3-14 July, hourly values.

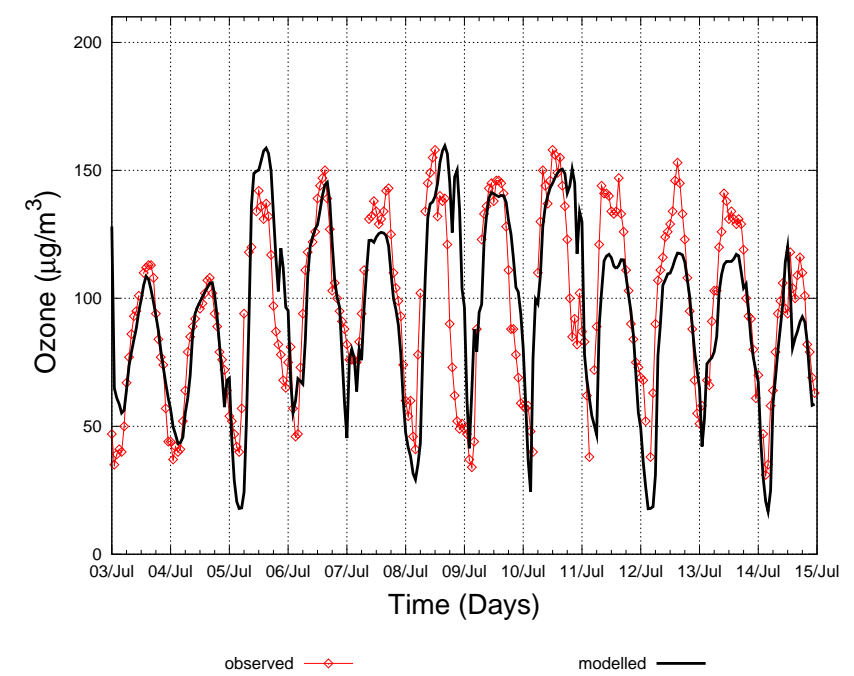

Fig. 6. Observed and modelled ozone time series at Zloty Potok; 3-14 July, hourly values.

\subsection{Temperature and $\mathrm{NO}_{2}$}

For better understanding of the observed and modelled variability of ozone concentrations, additional analysis was undertaken for the near-surface air temperature and $\mathrm{NO}_{2}$ concentrations. These two parameters control to a large extent ozone production efficiency. The temperature and $\mathrm{NO}_{2}$ measurements were taken in the same locations as for ozone. Temperature records were available from 7 stations (only from Poland) and $\mathrm{NO}_{2}$ measurements from 17 sites. The accuracy measures computed for the temperature show very good agreement between modelled and measured values. A

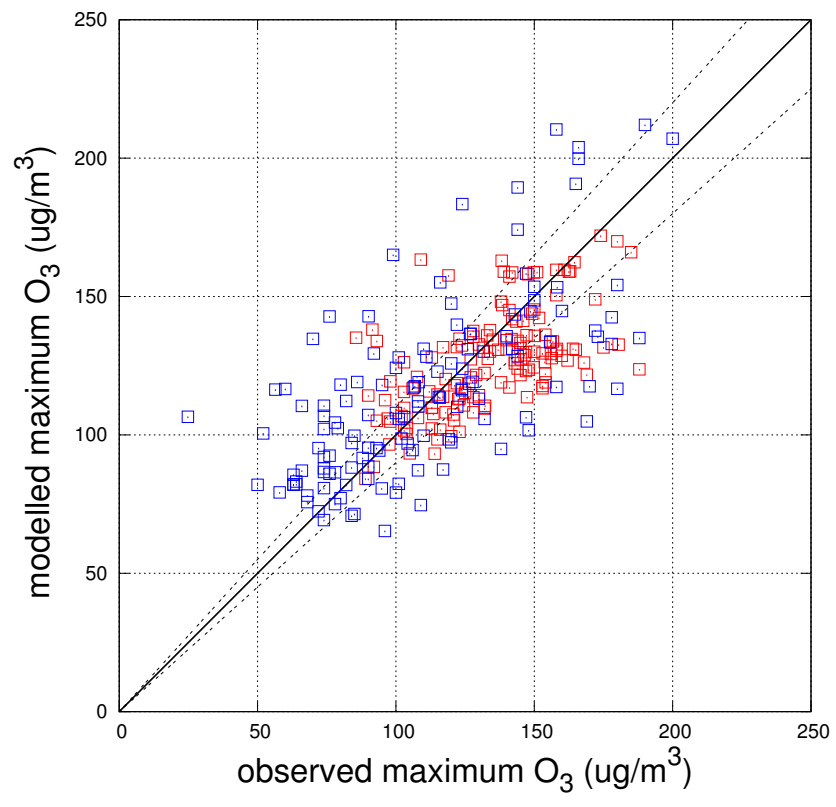

Fig. 7. Scatter plot of observed and modelled ozone maximum concentrations (red - Central Europe; blue - Western Europe).

Table 2. Error statistics for air temperature.

\begin{tabular}{lrrrr}
\hline $\begin{array}{l}\text { Station } \\
\text { Name }\end{array}$ & $\begin{array}{r}\text { Correlation } \\
\text { Coefficient }\end{array}$ & MBE & MAGE & RMSE \\
\hline Czerniawa & 0.84 & 1.57 & 2.30 & 2.76 \\
Jeleniow & 0.93 & -1.18 & 1.93 & 2.36 \\
Kedzierzyn Kozle & 0.95 & 1.81 & 2.24 & 2.72 \\
Krzyzowka & 0.92 & 1.99 & 2.36 & 3.02 \\
Mscigniew & 0.95 & 0.86 & 1.26 & 1.70 \\
Smolary Bytnickie & 0.95 & 1.92 & 2.18 & 2.98 \\
Widuchowa & 0.95 & 0.12 & 1.56 & 1.92 \\
\hline
\end{tabular}

high correlation coefficient $(\sim 0.94)$ indicates that the model performed well with respect to the diurnal cycle. Due to relatively small discrepancies the bias error and gross error are low. Positive values of MBE are mainly due to night time overestimation; MAGE (on average $\sim 2^{\circ} \mathrm{C}$ ) are only slightly higher than MBE (Table 2).

The analysis of time series and trend variability confirms the agreement between observed and modelled shelter-level temperature (Fig. 8). The night time minimum temperature is overestimated at most stations, especially for clearsky nights. The sharp temperature gradients in the surface layer, caused by cooling effects, are not reproduced by the model due to insufficient vertical grid resolution. Maximum temperature is predicted correctly with respect to the time of occurrence. During the second week of the episode (9-12 


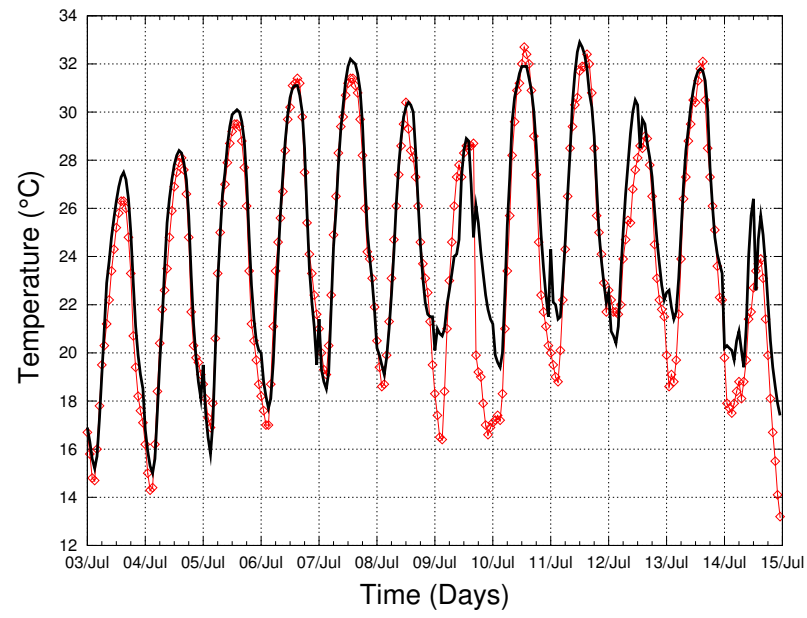

observed $\triangle \diamond \quad$ modelled -

Fig. 8. Observed and modelled temperature time series at Mscigniew; 2-14 July, hourly values.

July) the model under-predicted the maximum temperature at some stations (e.g. underestimation of near-surface temperature for 12 July is shown in Fig. 14a for temperature vertical profile for Legionowo).

Since a similar under-prediction was observed for ozone concentrations, the plausible reason might be the overestimation of the modelled cloud cover associated with the cold front that dissipated over Poland at that time. This resulted in reduction of the solar irradiance and led to underestimation temperature and, in consequence, biogenic emissions and ozone production efficiency.

The time series of temperature variation show a similar pattern for all analysed stations. The temperature increased significantly from 3 July to 7 July. During the next few days high temperatures persisted, but from 10 July to 12 July they decreased slightly due to the frontal activity. Due to the very slow movement of the frontal zone the dynamical forcing were not the same over the western and northeastern parts of Poland and hence near-surface temperature decrease was detected on different days at different measurement sites. After the frontal passage the temperature initially rose, but the change of wind direction and the inflow of colder air from northerly directions resulted in a temperature decrease. Figure 9 shows a scatter plot of observed and predicted shelter-level maximum temperature for all simulated days in all stations. The largest discrepancies are found for the lowest temperatures, probably impacted by the frontal activity. For the maximum temperatures below $\sim 30^{\circ} \mathrm{C}$ the model tends to overestimate, while for days with observed temperatures exceeding $\sim 30^{\circ} \mathrm{C}$ modelled maximum temperatures are slightly under-predicted. However, the differences between modelled and observed daily maximum temperatures are relatively small, and do not exceed $10 \%$.

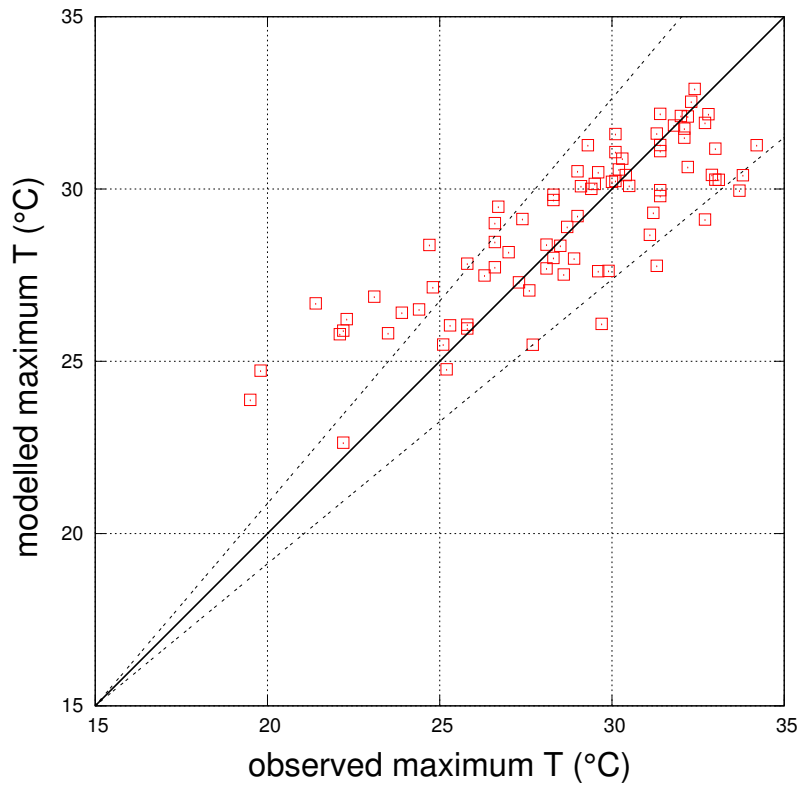

Fig. 9. Scatter plot of observed and modelled daily maximum temperature.

$\mathrm{NO}_{2}$ concentrations are shown in Figs. 10 and 11. The best agreement seems to be obtained for stations influenced mainly by anthropogenic emissions (Olkusz). At the monitoring sites where biogenic emissions are a dominant source, the agreement is the worst (Mscigniew). This is because the model uses predefined temporal variation profiles, and for biogenic emissions this profile is probably not representative for the extreme heat wave conditions. Moreover, the modelled $\mathrm{NO}_{2}$ concentration levels at these stations seem to be underestimated by comparison with measured values. At some stations modelled values were below the detection level of the measuring instrument.

\subsection{Vertical structure}

Many air quality models are designed for studying and forecasting near-surface air pollution. GEM-AQ model is a tropospheric chemistry model, hence, apart from the comparison against surface measurements, the analysis of the model's performance in reproduction of the observed vertical structure of the atmosphere was undertaken. Figure 12 presents ozone vertical soundings from the Centre of Aerology in Legionowo, for 5 July and 12 July. On 5 July the model overestimates ozone partial pressure below $\sim 800 \mathrm{hPa}$ of about $1 \mathrm{mPa}$. This corresponds to $\sim 10 \mathrm{ppb}$ near the surface, which agrees with analysis of surface measurements for the Legionowo station for that day. In the free troposphere, the model tends to underestimate the ozone partial pressure by $\sim 1 \mathrm{mPa}$ (corresponding to $\sim 16 \mathrm{ppb}$ at $600 \mathrm{hPa}$ ). Major discrepancies are found at $200 \mathrm{hPa}$. The observations show a 


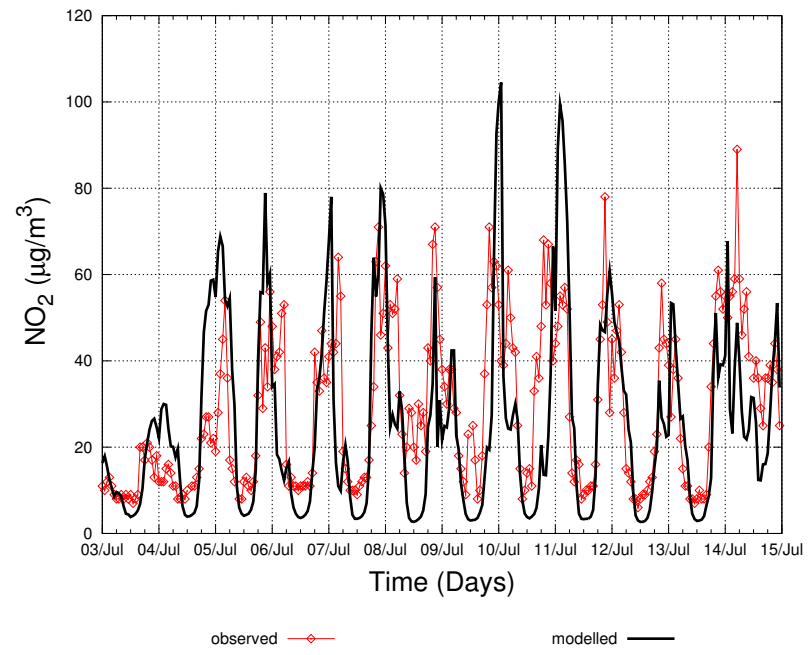

Fig. 10. Observed and modelled $\mathrm{NO}_{2}$ time series at Olkusz; 2-14 July, hourly values.

significant increase of ozone at that height, while the model did not capture this rapid increase.

On 12 July the model underestimated the ozone partial pressure within the boundary layer (below $700 \mathrm{hPa}$ ) by $\sim 1 \mathrm{mPa}$. In the free troposphere the agreement is very good, but above $200 \mathrm{hPa}$ the model slightly underestimates the measurements. The average gradient of the ozone profile is well represented in the troposphere.

To understand the differences of ozone structure within the boundary layer, the temperature, specific humidity and wind vertical sounding from Legionowo were analysed for the whole period of simulation. Figures 13 and 14 present measurements below $600 \mathrm{hPa}$.

For the first week of the simulation, when anticyclonic conditions governed weather patterns, the observed capping inversion layer, associated with large-scale subsidence, was not reproduced by the model due to insufficient vertical resolution. The modelled vertical structure of the lower troposphere shows a thicker, weak stable layer above the mixing layer. Defining the mixing layer top at the level where the stable layer begins and the specific humidity significantly decreases, the modelled height is usually underestimated during the daytime (12:00 UTC), as compared to observations. During the night time the agreement seems to be better despite the difficulties in reproducing the stable layer near the surface. On 5 July the largest discrepancies are found between $850 \mathrm{hPa}$ (modelled ABL top) and $\sim 750 \mathrm{hPa}$ (observed capping inversion). The modelled ABL being too shallow is a plausible reason for the ozone overestimation within $\mathrm{ABL}$ for that day. The effect of accumulation was enhanced by the underestimated wind speed. During the second week of the analysed period Central Europe was influenced by frontal activity, which resulted in lack of a strong capping inversion.

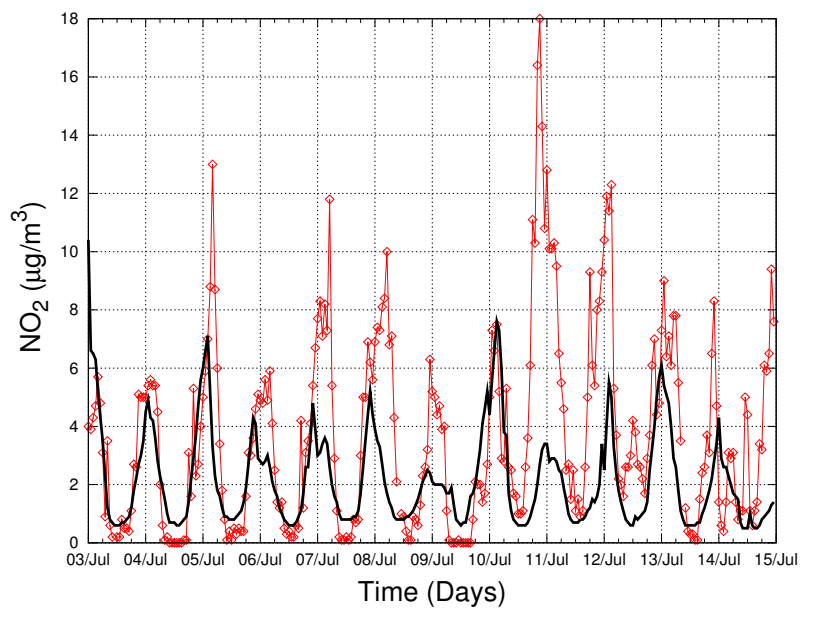

observed $\because \quad \quad$ modelled $\longrightarrow$

Fig. 11. Observed and modelled $\mathrm{NO}_{2}$ time series at Mscigniew; 2-14 July, hourly values.

In most cases the agreement of vertical profiles is good, especially for the daytime temperature. However, on 12 July the modelled temperature in the boundary layer was underestimated, and the temperature profile indicates a stable condition below $950 \mathrm{hPa}$. This effect was probably caused by overestimated modelled cloud cover on that day. Temperatures that were too low, weak vertical mixing and overestimated wind speed resulted in ozone underestimation within the boundary layer.

In general, the model's performance in reproducing the vertical structure of the lower troposphere is satisfactory. Discrepancies between modelled and observed ozone partial pressure are caused by insufficient vertical resolution, which had an impact on the modelled ABL structure. However, the pattern of variability and temporal evolution of ozone and meteorological parameters was captured well.

\subsection{Exposure indices for temperature and ozone}

The comparison with meteorological observations and air quality measurements confirmed good performance of the GEM-AQ model for the analysed period. Further investigation of the exposure to high air temperatures and elevated concentrations of ozone is based on model results. The maximum 8-h running average of ozone concentration was calculated for each day of the simulation. According to the WHO guidelines for Europe applied to European Ozone Directive 2002/3/EC (2002), the highest 8-h concentration of ozone should not exceed $120 \mu \mathrm{g} \mathrm{m}^{-3}$ for more than 25 days per year (target value for the year 2010). For the air temperature the 8-h average was calculated for the fixed time interval from 10:00 a.m. to 05:00 p.m. to represent mean daylight value.

On 3 and 4 July the average daylight temperature exceeded $27^{\circ} \mathrm{C}$ over Western Europe, with highest values over 
STN221 (52.4, 20.97) - 2006-07-05

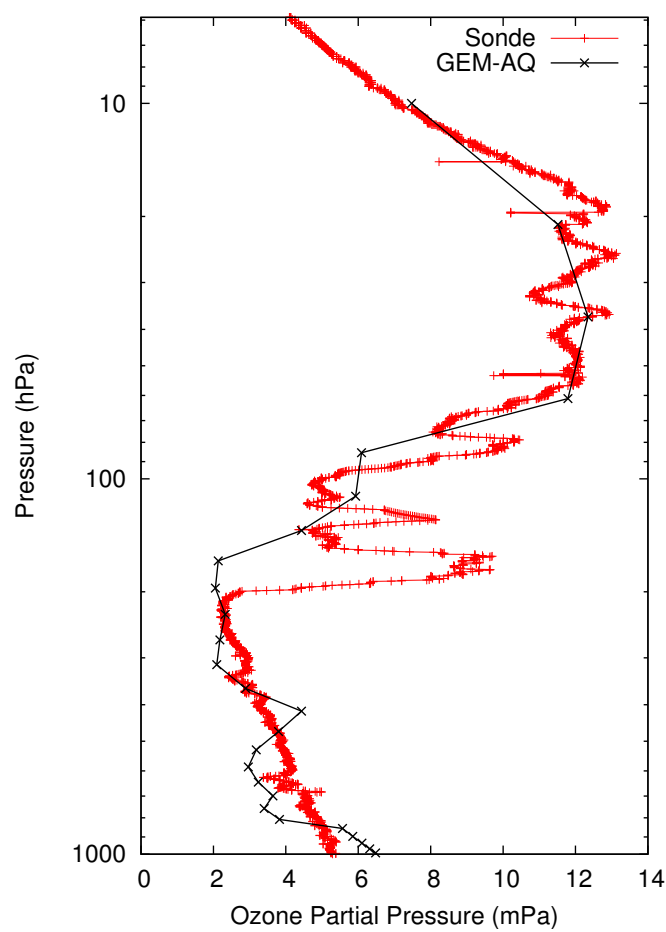

STN221 $(52.4,20.97)$ - 2006-07-12

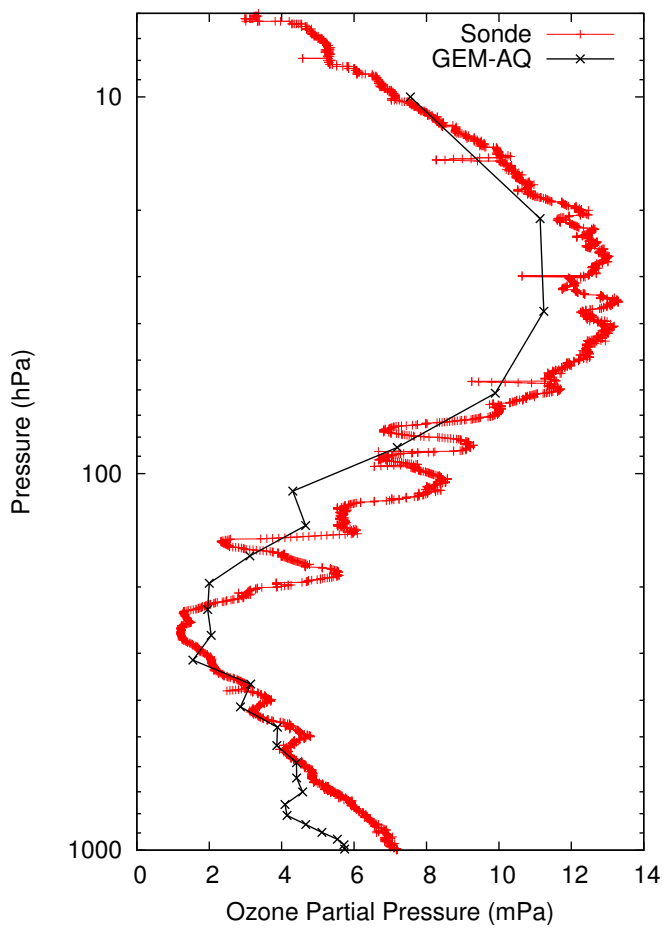

Fig. 12. Observed and modelled ozone vertical soundings from Legionowo; (a) 5 July, 12:00 UTC, (b) 12 July, $12: 00$ UTC.

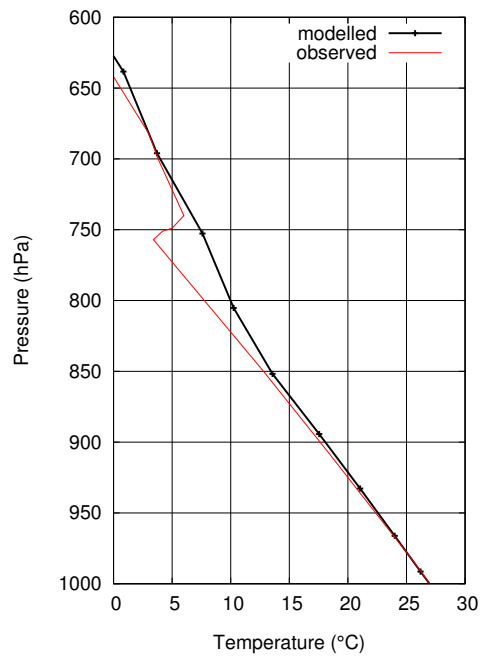

(a)

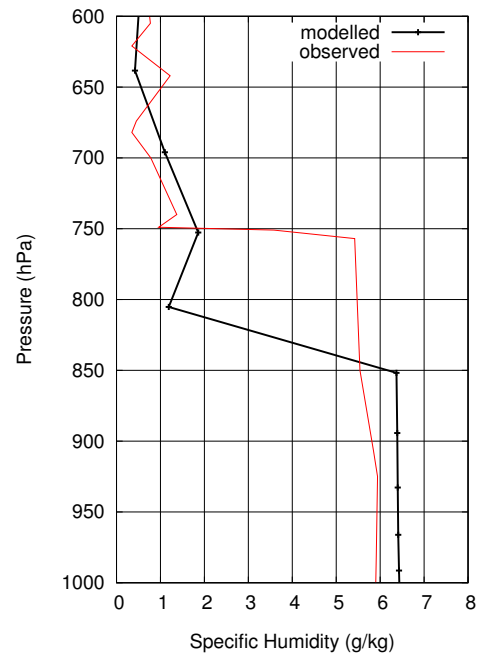

(b)

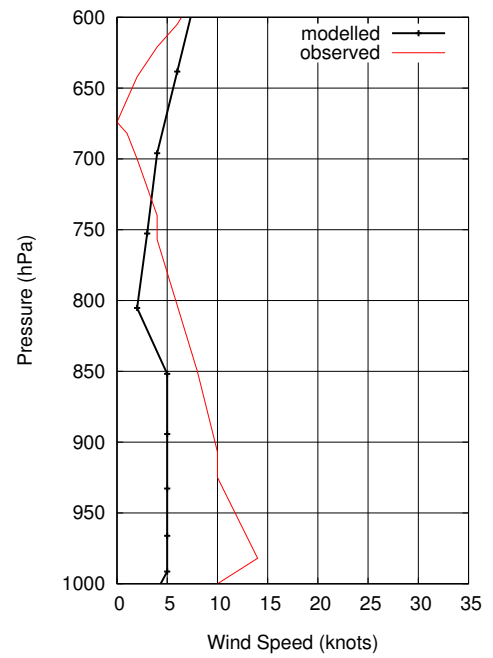

(c)

Fig. 13. Observed and modelled vertical profiles for Legionowo on 5 July, 12:00 UTC; (a) temperature, (b) specific humidity, (c) wind speed.

France. The 8-h modelled ozone concentrations higher than $120 \mu \mathrm{g} \mathrm{m}^{-3}$ occurred in Germany, the Netherlands, Belgium and UK. After 5 July hot air masses reached Central Europe and Scandinavia. The area exposed to 8-h ozone concentrations higher than $120 \mathrm{\mu g} \mathrm{m}^{-3}$ extended to the north (Den- mark, southern Norway and Sweden) and to the east (Poland, Lithuania, Czech Republic, Austria). From 7 July to 10 July the highest daylight air temperatures were recorded over Central-Eastern Europe (Fig. 15). Elevated concentrations of ozone were sustained over Central Europe and occurred 


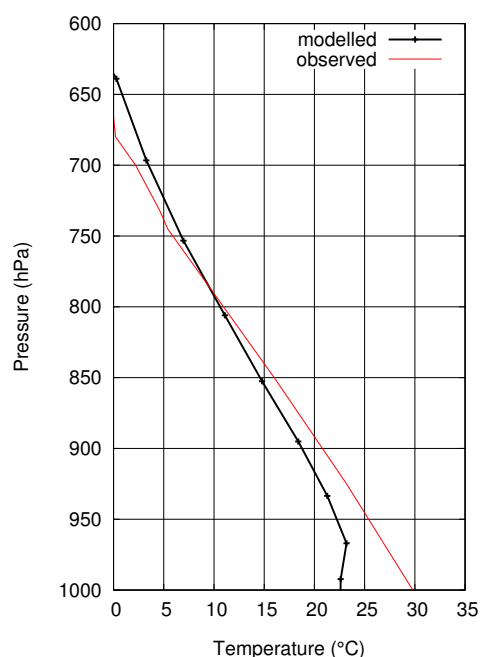

(a)

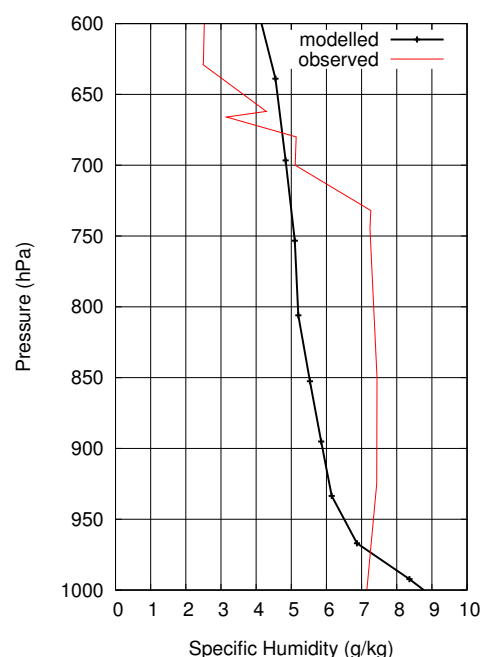

(b)

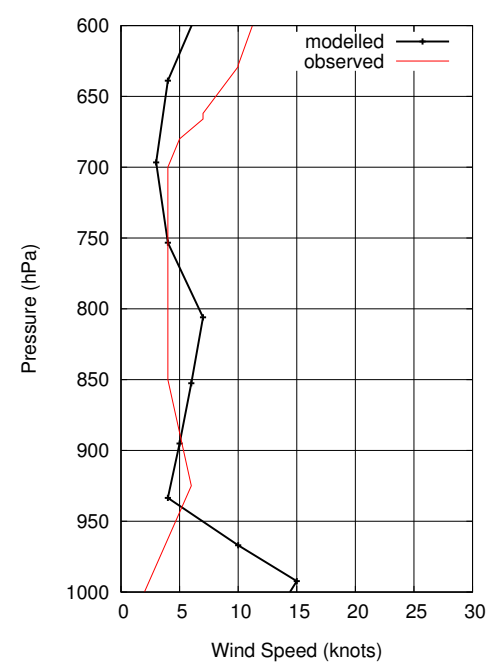

(c)

Fig. 14. Observed and modelled vertical profiles for Legionowo on 12 July, 12:00 UTC; (a) temperature, (b) specific humidity, (c) wind speed.
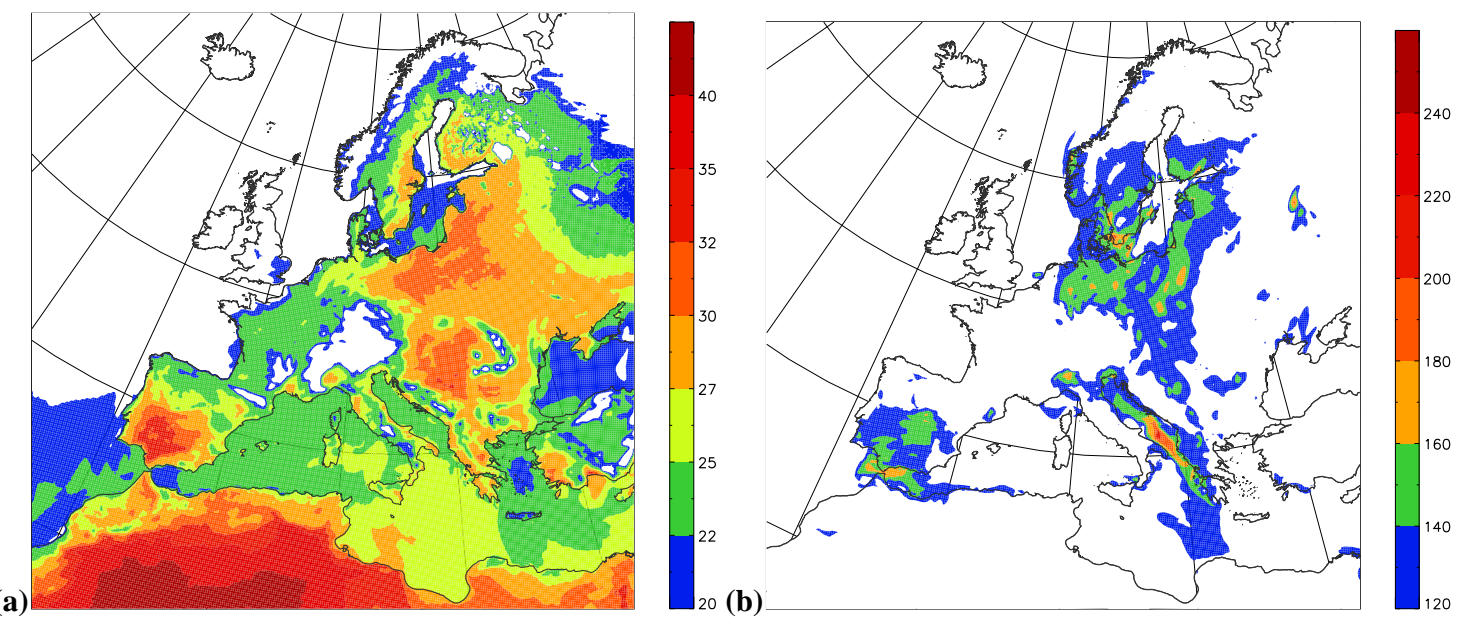

Fig. 15. Heat wave indicators; (a) 8-h averaged temperature for 8 July, (b) maximum 8-h average ozone concentrations for 8 July.

in Scandinavia and the Baltic countries. The average daylight temperatures higher than $30^{\circ} \mathrm{C}$ and 8 -h ozone averages exceeding $140 \mathrm{\mu g} \mathrm{m}^{-3}$ occurred in Poland, Lithuania, Latvia and Finland. On 11 July, despite the northern inflow, high temperatures were recorded over most of Europe. In Central-Eastern Europe very high ozone concentrations persisted and 8-h ozone average exceeded $140 \mu \mathrm{g} \mathrm{m}^{-3}$, but the clean air mass advected from the northerly direction terminated the episode over Scandinavia. After 12 July the heat wave returned to Western Europe; high temperatures were also recorded in Eastern Europe. Significant increases of ozone concentrations were recorded over Spain, France and Italy. At the same time inflow of a clear and cooler air mass from the north reduced ozone concentrations in Central Europe, reducing $\mathrm{O}_{3}$ below the 8-h average threshold on 14 July.

To assess the heat wave exposure the number of hours with the air temperature exceeding $30^{\circ} \mathrm{C}$ was calculated (Fig. 16a). Apart from South-Western Europe (Spain, southern France, northern Italy) two regions in Central Europe can be distinguished: The Hungarian Plateau $(50-70 \mathrm{~h})$ and the Eastern and Central European plateau $(40-50 \mathrm{~h})$. The maximum air temperatures are presented in Fig. 16b. The modelled values exceeded $32^{\circ} \mathrm{C}$ over most of Europe, even over the north-eastern part, near the Gulf of Finland $\left(60^{\circ} \mathrm{N}\right)$, which indicates the 

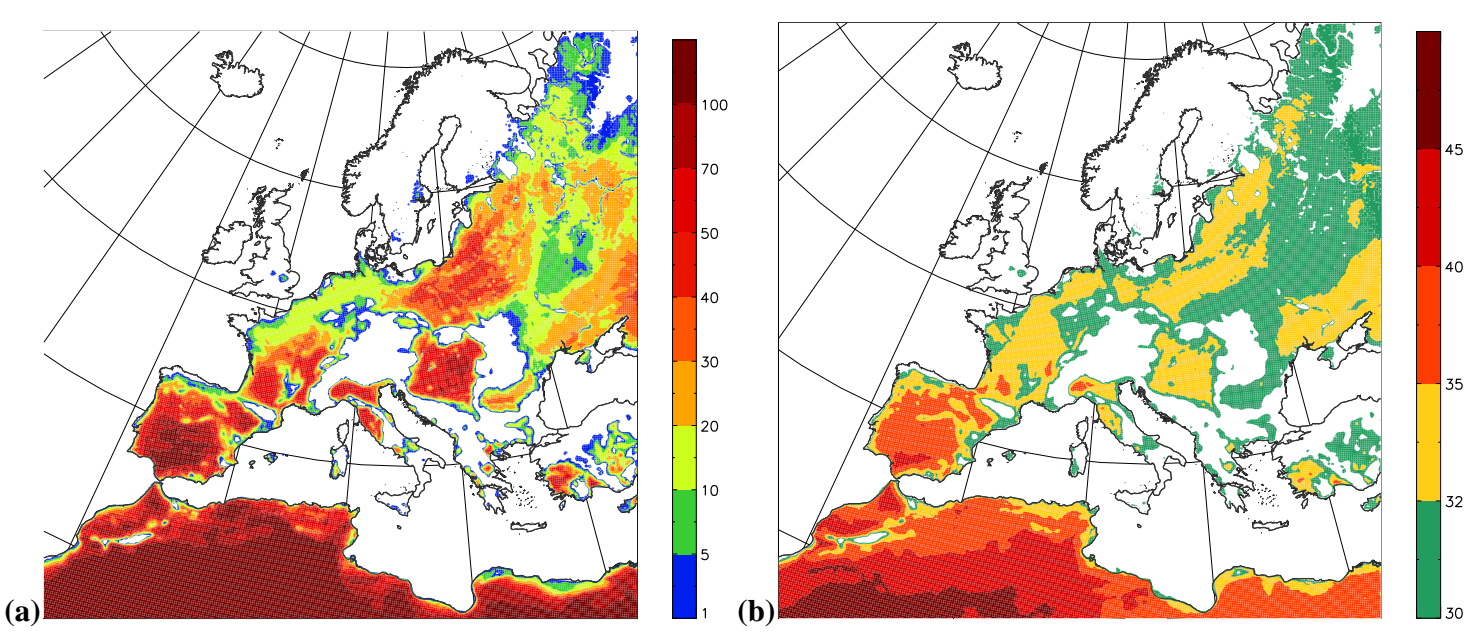

Fig. 16. Heat wave exposure; (a) number of hours with temperature exceeding $30^{\circ} \mathrm{C}$ over the simulation period, (b) maximum modelled air temperature over the simulation period.

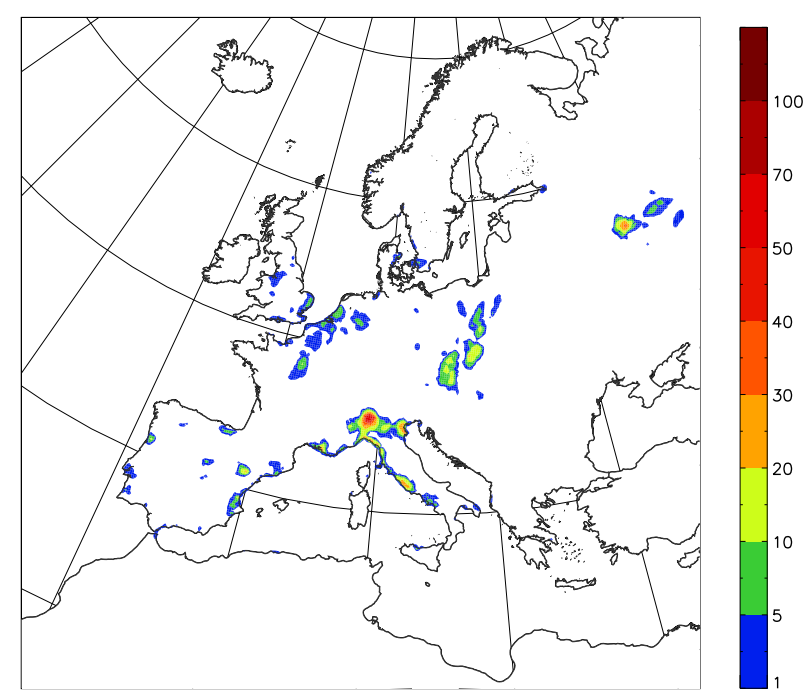

Fig. 17. Number of hours with ozone concentrations exceeding the information threshold $\left(180 \mu \mathrm{gm}^{-3}\right)$.

advective nature of the heat wave phenomenon in this region. It should be noted that during the analysed period in South-Eastern Europe (Southern Italy, Adriatic Sea basin, Greece, and Bulgaria) the temperatures were relatively lower than in other parts of the continent, and according to MODIS images (http://earthobservatory.nasa.gov/ NaturalHazards/shownh.php3?img_id=13765) lower than the 5-year (2000-2005) average for July.

The following indices defined in EU Ozone Directives 2002/3/EC were calculated to assess the exposure to photochemical pollution during the first two weeks of July 2006:
- number of hours with ozone concentrations exceeding the information threshold $\left(180 \mu \mathrm{g} \mathrm{m}^{-3}\right)$

- number of days with maximum 8-h ozone average exceeding $120 \mu \mathrm{g} \mathrm{m}^{-3}$

- SOMO35 (Sum Of Means Over 35 ppbv)

- AOT40 (Accumulated dose Over a Threshold of $40 \mathrm{ppbv})$

SOMO35 and AOT40 are time integrals of surface ozone concentrations greater than $35 \mathrm{ppbv}$ (for 8-h maximum ozone average) and $40 \mathrm{ppbv}$ (for hourly ozone mean concentrations), respectively. SOMO35 is a measure of human exposure and refers to the health-relevant WHO threshold of $120 \mu \mathrm{g} \mathrm{m}^{-3}$, while AOT40 is a critical level for forests and agriculture (WHO, 2000).

The number of hours with ozone concentrations exceeding the information threshold of $180 \mathrm{\mu g} \mathrm{m}^{-3}$ was calculated only over the land (Fig. 17). The location of occurrences of very high ozone concentrations seems to be related to the distribution of urban and industrial areas rather than to the heat wave extent. In Western and South-Western Europe the information threshold was exceeded only for a few hours (in the beginning and the end of the analysed period) around agglomerations. The highest number of hours with ozone concentrations exceeding $180 \mu \mathrm{g} \mathrm{m}^{-3}$ are in the Po Valley around Milan, where elevated ozone concentrations and very high temperatures persisted during the whole analysed period. In Central Europe (over Poland and Czech Republic) the number of information threshold exceedances ranged from 5 to $20 \mathrm{~h}$. The extent of very high ozone concentrations seem to be more widespread, but similar to other regions related to industrial areas. In Eastern Europe ozone exceedances are noted only in the vicinity of Moscow agglomeration. At 


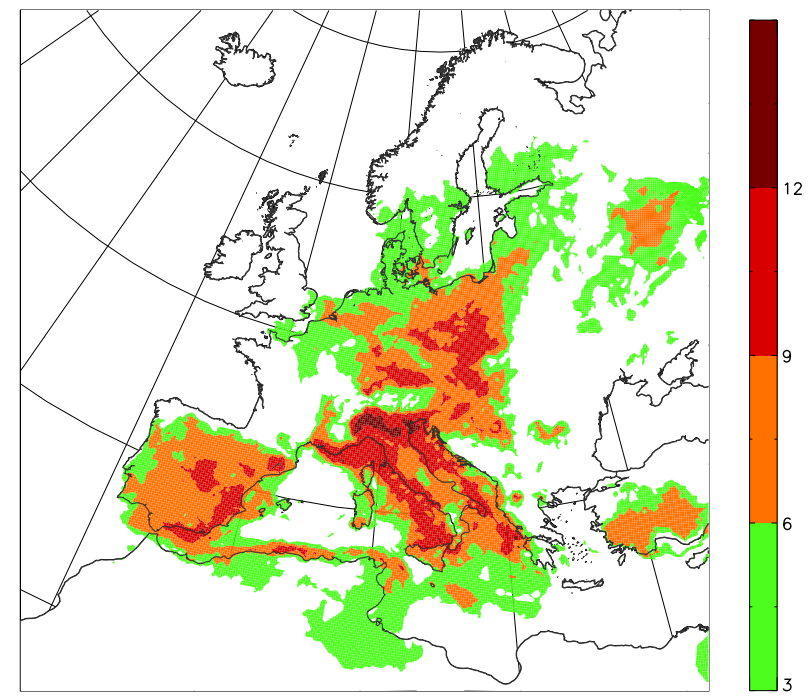

Fig. 18. Number of days with maximum 8-h ozone average exceeding $120 \mathrm{~g} \mathrm{~m}^{-3}$.

higher latitudes, despite the high temperatures, the information threshold was exceeded only three times around Helsinki and St. Petersburg. This indicated the importance of anthropogenic $\mathrm{NO}_{\mathrm{x}}$ emissions.

According to the EU directive relating to ozone (2002/3/EC) the human health exposure is defined by the number of days with maximum daily 8 -h mean ozone concentrations exceeding $120 \mathrm{~g} \mathrm{~m}^{-3}$. The target value for the year 2010 is 25 days per calendar year (averaged over three years). Figure 18 shows the distribution of the number of days characterised by 8 -h ozone average higher than the health protection threshold. During the analysed twoweek period the number of such days ranged from 6 to 12 over Central Europe (Poland, Czech Republic, Hungary) and Southern Europe (Spain, Italy). At higher latitudes (Sweden, Latvia, Estonia, Finland) the 8-h ozone averages were above the limit value from 3 to 5 days. The area exposed to a higher number of days with exceedances corresponds well to the occurrence of high temperatures in Central Europe and the Baltic countries. In Eastern Europe, in spite of high temperature and anticyclonic conditions favouring photochemical production, the modelled maximum and 8-h average ozone concentrations over Ukraine, Belarus and SouthWestern Russia were below the critical thresholds. These results cannot be confirmed due to the lack of available air quality measurements, but it is plausible. The industrial activity and the precursors' emissions over this area are lower than in Western and Central Europe. In addition, the divergence associated with the high pressure system prevented the inflow of polluted air masses from Central Europe.

Another health-related index - SOMO35 - has been proposed by WHO/UNECE Task Force on Health for an expo-

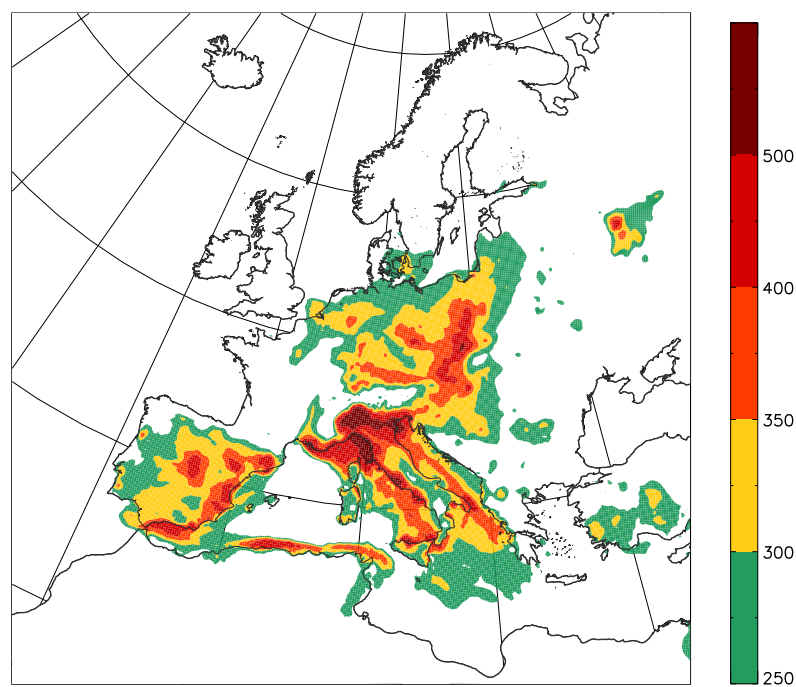

Fig. 19. SOMO35 index [ppb days] calculated for the simulation period.

sure proportional to the mortality (United Nations Economic and Social Council, 2004). In terms of impact, it is assumed that a decrease in the SOMO35 value of $600 \mathrm{ppb}$ days will reduce the number of premature deaths by approximately 13 people per million inhabitants (EEA, 2006). SOMO35 values calculated for the 12-day period are very high - in the range of 300-500 ppb days, and expand widely over Central and Southern Europe (Fig. 19). The highest values are over northern Italy and Central Europe. The zone of higher exposure extended from Genova Bay towards the Baltic countries, following the advection pattern of hot air masses from over Algeria, described in Sect. 2.1. However, at the higher latitudes the exposure is significantly lower and reached $250 \mathrm{ppb}$ days only over urban sites (Helsinki and St. Petersburg). In eastern Europe elevated values of SOMO35 are present around Moscow conurbation.

For the assessment of vegetation exposure, the AOT40 indicator was calculated. According to EU regulations (Directive 2002/3/EC, 2002), for sensitive crops the critical level is set at $3000 \mathrm{ppb}$ hours during the daytime over a three-month growing season (May-July). For forests, the critical level is set to $10000 \mathrm{ppb}$ hours, calculated over a six-month growing period. The AOT40 distribution calculated for the analysed period (Fig. 20) shows that in the first two weeks of July ozone levels already exceeded the 3-month critical exposure for crops. Over Central and Southern Europe AOT40 ranged from 3000 to $5000 \mathrm{ppb}$ hours. Taking into account that central Europe is an agriculture region, such high exposure to ozone concentrations accompanied by high temperatures and droughts resulted in significantly reduced harvest. The spatial distribution of exposure zones is similar to the SOMO35 index. 


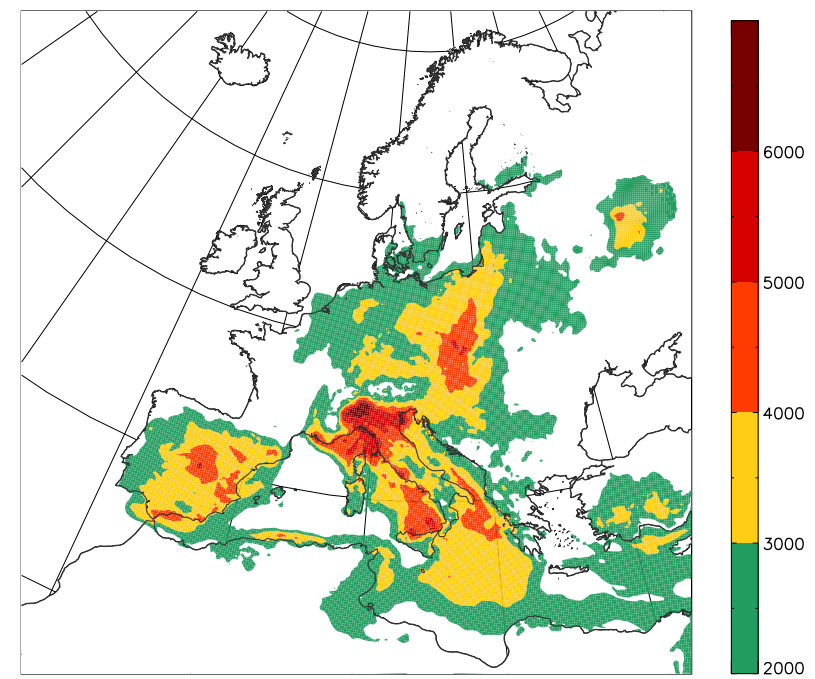

Fig. 20. AOT40 index [ppb days] calculated for the simulation period.

\section{Conclusions}

In the first two weeks of July 2006 a severe heat wave affected Central and North-Eastern Europe. In view of putative future increase of heat wave occurrences over Europe, the investigation of its impact on photochemical pollution levels over different geographical regions is of major importance.

The on-line tropospheric chemistry model GEM-AQ was used to simulate the meteorological situation and photochemical processes over Europe for the time span from 3 July to 14 July 2006. Based on modelling results, an attempt has been made to analyse the nature of the heat wave observed over Central and North-Eastern Europe in the beginning of July 2006 and to investigate related exposure on photochemical pollution. The ozone episode occurred over most of the area exposed to high temperatures. Based on modelling results, the zone of highest exposure was located over Central Europe along the advection path of the hot African air mass. At higher latitudes the heat wave impact was limited due to the advective nature of this phenomenon. The exposure to high ozone concentrations in this area was also reduced by the dilution and aging of polluted air masses advected from over Central Europe. In Eastern Europe, in spite of high temperature and anticyclonic conditions favouring photochemical production, elevated ozone concentrations (in terms of maximum hourly values and exposure indices) were modelled only around Moscow agglomeration. In South-Eastern Europe, negative temperature anomalies were noted, which should be further studied in terms of synoptic situation and advection pathways. The calculated ozone exposure was relatively low in this region and limited to urban agglomerations.
A general outcome from this study is that the impact of heat wave conditions on the photochemical pollution is controlled by many independent factors. The three major factors are: the circulation patterns, the geographical location (e.g. lower solar radiation flux in higher latitudes) and the intensity of anthropogenic $\mathrm{NO}_{\mathrm{x}}$ emissions. Circulation patterns seem to play the major role in the frequency of occurrence of heat waves over Central-Eastern Europe. Also, atmospheric circulation governs the advection and/or blocking of polluted air masses in this region. Despite the wide heat wave expansion towards north-eastern Europe, the calculated ozone exposure indices were relatively small in this area.

Assuming more frequent occurrence of the heat wave phenomena observed in July 2006, one can anticipate the increase of human and vegetation exposure indices (SOMO35 and AOT40) in central and North-Eastern Europe. Maximum concentrations would exceed information thresholds only in urban and industrial locations. However, the level of the exposure will strongly depend on applied emission reduction strategy in the future and on the possible changes in circulation patterns due to global and regional climate changes.

Acknowledgements. The authors wish to acknowledge financial support from the Canadian Foundation for Climate and Atmospheric Sciences, Environment Canada, the Canadian Foundation for Innovation, and the Ontario Innovation Trust. Also, we thank R. Girgzdiene for providing ozone measurements from Lithuania. The authors also thank the anonymous reviewers for their helpful comments.

Edited by: R. Vautard

\section{References}

Beniston, M. and Diaz, H. F.: The 2003 heat wave as an example of summers in a greenhouse climate? Observations and climate model simulations for Basel, Switzerland, Global Planet Change, 44, 73-81, 2004.

Côté, J., Gravel, S., Méthot, A., Patoine, A., Roch, M., and Staniforth, A.: The operational CMC-MRB Global Environmental Multiscale (GEM) Model. Part I: Design considerations and formulation, Mon. Weather Rev., 126, 1373-1395, 1998.

Directive 2002/3/EC: Directive 2002/3/EC of the European Parliament and of the Council of 12 February 2002 relating to ozone in ambient air, Official Journal of European Communities, L 067, 09/03/2002, 14-30, 2002.

DWD: Der Recordsommer 2003, Tech. rep., Deutscher Wetterdienst, http://www.dwd.de/de/WundK/Klimadaten, 2003.

EEA: Air quality and ancillary benefits of climate change policies, Tech. rep., European Environment Agency, 2006.

Fiala, J., Cernikovsky, L., de Leeuw, F., and Kurfuerst, P.: Air pollution by ozone in Europe in summer 2003, Tech. rep., European Environment Agency, 2003.

Filleul, L., Cassadou, S., MéDina, S., Fabres, P., Lefranc, A., Eilstein, D., Tertre, A. L., Pascal, L., Chardon, B., Blanchard, M. Declercq, C., Jusot, J.-F., Prouvost, H., and Ledrans, M.: The relation between temperature, ozone, and mortality in the nine 
French cities during the heat wave of 2003, Environ. Health Perspect., 114, 1344-1347, 2006.

Fisher, P. H., Brunekreef, B., and Lebret, E.: Air pollution related deaths during the 2003 heat wave in the Netherlands, Atmos. Environ., 38, 1083-1085, 2004.

Gauthier, P., Tanguay, M., Laroche, S., Pellerin, S., and Morneau, J.: Extension of 3D-Var to 4D-Var: implementation of 4D-Var at the Meteorological Service of Canada, Mon. Weather Rev., 135, 2339-2354, 2007.

Hémon, D. and Jougla, E.: Surmortalité liée à la canicule d'août 2003, Rapport d'étape INSERM, Paris, 2003.

IPCC: The Scientific Basis: Contribution of Working Group I to the Third Assessment Report of the Intergovernmental Panel on Climate Change, in: Climate Change 2001, edited by: Houghton, J., Ding, Y., Griggs, D., Noguer, M., van der Linden, P., and Xiaosu, D., Cambridge University Press, Cambridge, 881 pp., 2001.

Jendritzky, G., Bucher, K., and Bendisch, F.: Die Mortalitatsstudie des Deutschen Wetterdienstes, Annalen der Meteorologie, 33, 46-52, 1997 (in German).

Jones, P. D. and Moberg, A.: Hemispheric and large-scale surface air temperature variations: An extensive revision and an update to 2001, J. Climate, 16, 206-223, 2003.

Kaminski, J. W., Neary, L., Struzewska, J., McConnell, J. C., Lupu, A., Jarosz, J., Toyota, K., Gong, S. L., Liu, X., Chance, K., and Richter, A.: GEM-AQ, an on-line global multiscale chemical weather system: model description and evaluation of gas phase chemistry processes, Atmos. Chem. Phys. Discuss., 7, 14895 14 937, 2007.

Katsouyanni, K., Trichopoulos, D., Zavitsanos, X., and Touloumi, G.: The 1987 Athens heatwave, Lancet, 573, 1988.

Katsouyanni, K., Pantazopoulou, A., and Touloumi, G.: Evidence for interaction between air pollution and high temperature in the causation of excess mortality, Archives of Environmental Health, 48, 235-242, 1993.

Kunst, A. E., Looman, C. W. N., and Mackenbach, J. P.: Outdoor air temperature and mortality in the Netherlands: a time-series analysis, An. J. Epidemiol., 137, 331-341, 1993.

Kysely, J.: Mortality and displaced mortality during heat waves in the Czech Republic, Int. J. Biometeorol., 49, 91-97, 2004.

Langmann, B.: Numerical modelling of regional scale transport and photochemistry directly together with meteorological processes, Atmos. Environ., 34, 3585-3598, 2000.

Laroche, S., Gauthier, P., Tanguay, M., Pellerin, S., and Morneau, J.: Impact of the different components of 4D-Var on the global forecast system of the Meteorological Service of Canada, Mon. Weather Rev., 135, 2355-2364, 2007.

Lee, J. D., Lewis, A. C., Monks, P. S., Jacob, M., Hamilton, J. F., Hopkins, J. R., Watson, N. M., Saxton, J. E., Ennis, C., Carpenter, L. J., Carslaw, N., Fleming, Z., Bandy, B. J., Oram, D. E., Penkett, S. A., Slemr, J., Norton, E., Rickard, A. R., Whalley, L. K., Heard, D. E., Bloss, W. J., Gravestock, T., Smith, S. C., Stanton, J., Pilling, M. J., and Jenkin, M. E.: Ozone photochemistry and elevated isoprene during the UK heatwave of August 2003, Atmos. Environ., 40, 7598-7613, doi: 10.1016/j.atmosenv.2006.06.057, 2006.

Liu, S. C., Trainer, M., Fehsenfelf, F., Parrish, D. D., Williams, E. J., Fahey, D. W., Hubler, G., and Murphy, P. C.: Ozone production in the rural troposphere and the implications for regional and global ozone distribution, J. Geophys. Res., 92, 4191-4207, 1987.

Lyamani, H., Olmo, F. J., Alcantara, A., and Alados-Arboledas, L.: Atmospheric aerosols during the 2003 heat wave in southeastern Spain I: Spectral optical depth, Atmos. Environ., 40, 6453-6464, 2006.

Mailhot, J., Belair, S., Lefaivre, L., Bilodeau, B., Desgagne, M., Girard, C., Glazer, A., Leduc, A. M., Methot, A., Patoine, A., Plante, A., Rahill, A., Robinson, T., Talbot, D., Tremblay, A., Vaillancourt, P., Zadra, A., and Qaddouri, A.: The $15-\mathrm{km}$ version of the Canadian regional forecast system, Atmospheric-Ocean, 44, 133-149, 2006.

McMichael, A. J. and Kovats, R. S.: Assessment of the impact on mortality in England and Wales of the heatwave and associated air pollution episode of 1976, Tech. rep., Department of Health, London School of Hygiene and Tropical Medicine, London, United Kingdom, 1998

Memmesheimer, M., Jakobs, H. J., Tippke, J., Ebel, A., Piekorz, G., Weber, M., Geiss, H., Jansen, S., Wickert, B., Friedrich, R., Schwarz, U., and Smiatek, G.: Simulation of summer-smog episode in July 1994 on the European and urban scale with special emphasis on the photo-oxidant plume of Berlin., in: A contribution to the subproject GLOREAM and GENEMIS., edited by: Borrel, P. M. and Borrel, P., WITPress, Southampton, 1999.

Olivier, J. G. J., Bouwman, A. F., van der Maas, C. W. M., Berdowski, J. J. M., Veldt, C., Bloos, J. P. J., Visschedijk, A. J. H., Zandveld, P. Y. J., and Haverlag, J. L.: Description of EDGAR version 2.0: A set of global emission inventories of greenhouse gases and ozone-depleting substances for all anthropogenic and most natural sources on a per country basis and on a $1 \times 1$ degree grid, RIVM report 771060 002/TNO-MEP report R96/119, Tech. rep., National Institute of Public Health and the Environment, Bilthoven, The Netherlands, 1996.

Rooney, C., McMichael, J. J., Kovats, R. S., and Coleman, M. P. Excess mortality in England and Wales, and in Greater London, during the 1995 heatwave, Epidemiol Community Health, 52, 482-486, 1998.

Sartor, F., Snacken, R., Demuth, C., and Walckiers, D.: Temperature, ambient ozone levels, and mortality during summer 1994, in Belgium, Environ. Res., 70, 105-113, 1995.

Schär, C., Vidale, P. L., Luthi, D., Frei, C., Haberli, C., Liniger, M. A., and Appenzeller, C.: The role of increasing temperature variability in European summer heatwaves, Nature, 427, 332336, 2004.

Scherrer, S. C., Appenzaller, C., Liniger, M. A., and Schär, C.: European temperature distribution changes in observations and climate change scenarios, Geophys. Res. Lett., 32, L19705, doi:10.1029/2005GL024108, 1-5, 2005.

Simpson, D., Guenther, A., Hewitt, C. N., and Steinbrecher, R.: Biogenic emissions in Europe. 1. Estimates and uncertainties, J. Geophys. Res., 100, 22 875-22 890, 1995.

Simpson, D., Winiwarter, W., Börjesson, G., Cinderby, S., Ferreiro, A., Guenther, A., Hewitt, C. N., Janson, R., Khalil, M. A. K., Owen, S., Pierce, T. E., Puxbaum, H., Shearer, M., Skiba, U., Steinbrecher, R., Tarrasón, L., and Öquist, M. G.: Inventorying emissions from nature in Europe, J. Geophys. Res., 104, 81138152, 1999.

Stedman, J. R.: The predicted number of air pollution related deaths in the UK during the August 2003 heatwave, Atmos. Environ., 
38, 1087-1090, 2004.

Tressol, M., Brioude, J., Mari, C., Thouret, V., Zbinden, R., and Cammas, J.-P.: Impact of Portugal fires on 2003 European pollution, Geophys. Res. Abstr., 8, 07357, 2006.

United Nations Economic and Social Council: Modelling and assessment of the health impact of particulate matter and ozone, Summary report prepared by the joint Task Force on the Health Aspects of Air pollution of the WHO/ECEH and the Executive Body, 2004.
Vautard, R., Honore, C., Beekmann, M., and Rouil, L.: Simulation of ozone during August 2003 heat wave and emission control scenarios, Atmos. Environ., 39, 2957-2967, 2005.

WHO: Air Quality guideline for Europe, in: WHO Regional Publications Second edition for Europe, Copenhagen, 2000.

WHO: Extreme weather and climate events and public health responses, in: Report on a WHO meeting Bratislava, EUR/04/5036 794, Slovakia, 9-10 February 2004, World Health Organization, Regional Committee for Europe, 2004. 